Дивна Васић

Средњошколски центар

„Иво Андрић“, Вишеград

821.163.41.09 Андрић И. https://doi.org/10.18485/ai_andric.2018.ch20

\title{
АНДРИЋЕВА ЈУНАКИЬА ЛОТИКА КАО ПРОТОТИП САВРЕМЕНЕ ПОСЛОВНЕ ЖЕНЕ
}

Тема рада обухвата историјски и друштвени тренутак у коме је живјела и стварала Јеврејка Лотика као представник новог доба, нових вриједности и новог типа жене - пословне, предузимљиве, еманциповане. Успјела је као странкиња, у босанској касаби и мушком свијету у коме владају патријархални односи, да постане прва пословна жена и узор многим газдама тог доба. Рад, стицање, умијеће опхођења са људима, донијели су јој новац и иметак, али и велике бриге и изазове. Њена изванредна способност уздиће је до опасних висина и на крају срушити и пословно и психички.

Кључне ријечи: Лотика, нове вриједности, пословна жена, успон, пад.

\section{1. Андрићеви суграђани} као безвремени литерарни јунаци

Познато је да је Иво Андрић за оквир свог романа На Дрини ћуӣрија користио историјске периоде, збивања и друштвене токове, као и судбине људи и колектива условљене догађајима у распону од четири вијека. Роман је, како је примјетио књижевни критичар „синтеза свих његових накнадних сазнања и историјских 
студија о Вишеграду и околини а још у већој мери збир доживљаја из времена детињства и младости“1.

Сам Андрић је истицао да је познавао неке од својих књижевних јунака, са неким од њих се и дружио, или је за њихове судбине чуо из прича суграђана. Обични људи, из забите босанске касабе, хришћани, муслимани и Јевреји, стварне су личности које је писац умјетнички оживио. Посебно интересантно су испричане судбине вишеградских Јевреја. У роману, тек у поглављу (XIV) када почиње прича о новим временима Андрић каже:

„Поред шпанских Јевреја, сефарда, који ту живе већ стотинама година, јер су се доселили некако у исто време када је грађен мост на Дрини; сад су придошли и галицки Јевреји, ашкенази“.2

Доласком Аустроугарске монархије досељава се и знатан број ашкенаских породица. Њима, који су се доселили из словенских покрајина сличан језик омогућио је бржу интеграцију. Њихов долазак био је прије свега, економски оправдан, јер се отварају велики јавни радови и сигурни разноврсни послови. То је био подстицај и за домаће хришћанско и муслиманско становништво, да се укључује у нове послове које су покренули предузимљиви дошљаци. „Као свежа крв кроз земљу је стао да кружи новац у дотле невиђеним количинама и што је главно, јасно, смело и отворено. На тој узбудљивој акумулацији злата, новца и сталне хартије, свак је могао да огреје руке или бар да 'напари очи' јер је она и код најсиромашнијег човека изазивала илузију да је његова оскудица само пролазна и стога подношљива. “3

1 Радован Вучковић. Анgрић - иаралеле и рецейција. Београд: Свет књиге, 2006, стр. 241.

2 Иво Андрић, На Дрини ћуприја, Сарајево 1988, стр. 158.

3 Ibid, стр 158. 
Један од таквих стварних ликова које је Андрић умјетнички уобличио и студиозно развио је лик пољске Јеврејке Лотике Лоти Целермајер.

\section{2. Лотика на позорници живота - успон и пад}

Прича о Lотики ${ }^{4}$, лијепој удовици из Тарнова и новом времену почиње у роману од XIV поглавља.

4 Лотика Лоти Целермајер (1860, Краков, Пољска) - Најпознатија Јеврејка, јунакиња Андрићевог романа, На Дрини ћуйрија. Најстарија је од три сестре Целермајер (Лотика, Дебора и Аделаида Адела) које су се крајем деветнаестог вијека доселиле у Вишеград. О њеном животу прије доласка, о њеном дјетињству и младости, скоро да се ништа не зна. Врло млада је остала удовица, већ у двадесетој години живота. Убрзо послије смрти мужа доктора, са сестрама се сели у Вишеград, који је тада дио Аустроугарске.

О њеном животу у Вишеграду зна се много више. Управљала је хотелом - ZUR BRUCKE - кога су мјештани једноставно звали Лотикин хотел. Стварни власник хотела био је муж њене сестре Деборе, Абрахам Цилер. Зграда хотела, која и данас постоји, зидана је 1891. године, уписана у катастарске књиге 1905. године, а власник је била Трговачка твртка из Сарајева. Послиједњи власник прије продаје зграде био је Фрањо Челина. Нови власници 1907. године постају Абрахам Цилер и Лотика Целермајер. Умрла је и сахрањена је на Јеврејском гробљу на Околишту 15.2.1938. год. у 78-ој години живота. Лотикина сестра Дебора и њен муж Абрахам Цилер које Андрић, такође, помиње у роману, умрли су и сахрањени у Вишеграду.

Дебора Цилер умрла је 20.01.1933. године у 62-ој години.

Абрахам Цилер умро је 03.11.1935. године у 76-ој години живота. Послије Лотикине смрти хотел су до Другог свјетског рата водиле њене сестричине Хелена и Серафина - Ина. У току рата, приликом бомбардовања, хотел је оштећен. Послије рата Хелена Цилер се вратила у Вишеград с намјером да зграду обнови или прода, али није успјела ни једно ни друго. Хотел је национализован 1959. године. Деценијама је био у власништву угоститељског предузећа „Панос“. Послије овог, посљедњег рата, приватизован је и нови власник издаје дио зграде. 
Европеизација уморне оријенталне касабе почела је са доласком нове власти; њу чине углавном странци, који су остављали утисак реда и чврстоће. Промјене су се дешавале брзо: нов ред, нов начин облачења, нов начин схватања, нове навике и замах у пословању, збуњивале су овдашње неповјерљиво становништво. Без силе и притиска, за разлику од претходне, отоманске власти, извукли су од народа новац за порезе и намете.

По неком реду у касабу прво долазе војници и жандарми, затим чиновници и трговци, а за њима се досељава становништво и цијеле породице из удаљених крајева аустроугарске државе.

Придошли странци искористили су „урођену склоност Вишеграђана ка безбрижном животу и ужи-

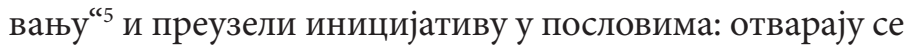
радње мјешовите робе, јувелирске радње, кантине, фабрике... и сви су налазили свој рачун и почели стицати.

У периоду од неколико деценија мира и благостања, најуспјешнија у пословању била је „Лотика, млада савршено лепа жена, слободног језика и мушке одрешитости“"

У касабу је дошла из Галиције са породицом сестре Деборе. У периоду од неколико деценија водила је први хотел у Вишеграду (Hotel zur Brücke) који је народ једноставно звао - Лотикин хотел. Стварни власник хотела, који се налазио на обали ријеке, поред саме ћуприје, био је муж њене сестре, Јеврејин Цилер. Ова неуморна, вјешта и отресита млада жена, по свему је представник новог доба: по начину пословања, савршено сигурном опхођењу према гостима, стицању новца, облачењу и манирима.

$5 \quad$ Ibid, cтp. 218.

6 Ibid, стр. 161. 
Није било лако водити хотел и носити се са проблемима доконих касабалија. Предузимљива и мудра, брзо је схватила навике и психологију људи уског и скученог видокруга. Свој начин пословања прилагодила је овдашњим условима и само са једним циљем - остварити зараду. И у томе је успјела - зарадила је много и стекла читав иметак.

Њено пословно начело било је: водити хотел без скандала (Nur kein skandal!).

Невелики хотел са собама на спрат, имао је чисте и пристојне опремљене собе и двије сале: велику, у коју је долазио обичан свијет и малу, одвојену вратима од непрозирног стакла са натписом: EXTRA ZIMMER, гдје су долазили богатији и угледнији гости (официри, чиновници, инжењери, газде) и они се нису мијешали са обичним гостима.

Особље хотела чинили су људи од повјерења, такође странци; келнерица Малчика, Мађарица, „calkelner“ Густав, чешки Њемац, и момак Милан Личанин, који је водио рачуна о реду у хотелу.

Њихов задатак је био да упознају све госте, њихове навике, платежну моћ, нарав, да знају кога треба пустити у хотел, а кога не. Водили су рачуна да гости што више пију и уредно плаћају. Лотика је пак, била задужена за боље, пробране госте, за разговоре и дружења са њима.

„Са свима њима она је разговарала слатко, смело, духовито, оштро, ласкаво, умирујуће.“7

Радила је много, до преморености, а о њеној способности писац каже: „Та мудра и човечна жена, које не мисли на себе, грабжљива а несебична, лепа и заводљива а чедна и хладна, води један паланачки хотел и праз-

$7 \quad$ Ibid, cтp. 218. 
ни џепове касабалијским севдалијама. Можда би била једна од оних чувених жена о којима историја говори и које управљају великим породицама, дворова или држава, окрећући увек све ствари набоље“.

У кратким тренуцима предаха повлачила се у своју собу. Скривена од свих и сама, сређивала је рачуне, пратила стање на берзи, трговала акцијама, одговарала на писма.

То је био дио њеног правог живота, озбиљног и тешког.

Новац који је зарадила трошила је на своје сиромашне рођаке, помагала, школовала, женила и удавала њихову дјецу, бринула о сународницима; једном ријечју свима била ослонац и сигурност. То је било друго лице ове усамљене жене, пуне пословних и породичних брига...

\section{1. Клонуће и слом Лотикиног живота}

Умор и слом дошли су у исто вријеме када и друштвене промјене. Дошла су „нова времена, нове идеје и нов начин живота“". Било је то вријеме „анексионе кризе“ када почиње урушавање свих пређашњих вриједности које су довеле до просперитета. Хотел је слабо радио, гомилали су се дугови и обавезе. „Бестидни простак Тердик“ отворио је срамну кућу и привукао све њене госте. Ударци су се низали један за другим; бринула је о сестриној дјеци; оне које је помагала и од којих је највише очекивала, разочарали су је.

На њу више нико није мислио.

А онда долази рат и стална гранатирања моста. Била је принуђена да са породицом пређе на лијеву обалу, у напуштену турску кућу. И „први пут откако зна за себе издала је снага, и то сва одједном. Пустом

$8 \quad$ Ibid, стр. 220.

9 Ibid, стр. 378. 
турском кућом проломио се њен јаук: нешто што никад нико није видео ни чуо, ни слутио да може да постоји. Лотикин плач, грозан и тежак као мушки а незадржаван и незадржљив. Али у породици је настало запрепашћено, готово побожно ћутање, па затим општи лелек и ридање. За њих је слом тетка-Лотикине снаге био тежак ударац него и бежање и губитак куће и кућишта, јер са њом се дало све пребродити и савладати,а без ње се није могло ништа урадити ни замислити. “10

Био је то слом живаца, слом тијела, слом живота испуњеног радом, умором и одрицањем. Њен крик, страшан као грмљавина, сломио је психички Лотику која је економски већ била уништена.

Али да је живот „несхватљиво чудо“ и да су могући свакојаки обрти, видимо у поглављу (XXIII) када писац завршава и причу о Лотики. Цилер, отежали и незаинтересовани Јеврејин, који је живио у сјени способне свастике, када се суочио са сломом остарјеле и немоћне жене, усправио се и постао оно што је одувијек и требао да буде - заштитник и глава породице.

Очајни јаук и грмљавина топова у даљини, наговјештавају надолазеће несреће: „То је начинио рат од Лотикиног хотела и његових становника. “11

\section{3. Умјесто закључка}

„Просте и убоге средине су позорнице за чуда и велике ствари“"12, рекао је Андрић, показујући и судбином ове јунакиње истину, да је ова ријетко мирна касаба била непресушан извор пишчев. Понекад се чини, да није писца и хроничара Андрића не бисмо познава-

$10 \quad$ Ibid, стр. 379.

11 Ibid, стр. 380.

12 Иво Андрић. Разі̄овор са Гојом. Сарајево, 1978. 
ли прошлост и судбине људи различитих по вјери, поријеклу и схватањима. Да није приче о Лотики, њеном

успону и паду, да ли бисмо знали да је становништво ове касабе живјело између привидно мирних година када су стварали „нешто“ и оних несрећних, када су губили све?

Једна неуморна жена, чијој су се љепоти, отмјености и способности дивиле генерације касабалија, доживљава пад. Напорним радом и одрицањем, успјела је у затвореној патријархалној средини да се избори за своје мјесто и буде узор младим газдама.

По свему је била посебна, по начину вођења хотела и цијеле породице, по начину запажања и пожртвованости. На крају, ова пословна жена савремених схватања, остаје без наде и утјехе. На низбрдици живота, она само види „последњи лук моста на слабој месечини“.

Њена судбина, њен успон до неслућених висина и њена пропаст, послужили су „за велике ствари“ истичући јединственост, поруке и дубину пишчеве мисли.

\section{Извори и литература}

Андрић, Иво. На Дрини ћуиррија. Свјетлост: Сарајево, 1978

Андрић, Иво. Љубав у касаби и gруіе вишеїраgске йриче. Београд: Чигоја штампа, 2005

Вучковић, Радован. Анgрић: йаралеле и рецейщија. Београд: Свет књиге, 2006

Јандрић, Љубо. Са Ивом Анgрићем. Светлост: ИРО Веселин Маслеша, 1982

Коџо, Милан. Кулитира вишеїраgскоі̄ краја (Необјављен рукопис)

Пинто, Аврам. Јевреји Сарајева и БиХ. Сарајево: Веселин Маслеша, 1987

Поповић, Радован. Анgрић и Buщеі̄pag. Београд: Чигоја штампа, 2005 
Ресулбеговић-Дефтедаровић, Азиз. Вишеїраg и околица (Ре$\bar{u}$ ринй изgань из 1934. ìog). Београд: Чигоја штампа, 1999 Билтен удружења усељеника из бивше Југославије у Израелу, бр. 6, децембар 2009 (Текст Јасне Ћирић)

Divna Vasić

\section{ANDRIĆ'S HEROINE LOTICA AS A PROTOTIP OF MODERN BUSINESS WOMEN}

\section{SUMMARY}

The theme of the paper encompasses the historical and social moment in which lived and worked Jewess Lotika as a representative of the new age, new values and a new type of woman - business, entrepreneurial, emancipated. She has succeeded as a foreignes, in the Bosnian kasaba and in the male world in which patriarchal relations are governed, to become the first business woman and model for many owners of that time. The work, acquiring, the skills of dealing with people, brought her money and possessions, but also big worries and challenges. Her extraordinary ability elevates her to dangerous heights and ultimately demolish. fall.

Key words: Lotika, new values, business woman, climb, 